\title{
Assessment of trace metal contamination in mangrove ecosystems from Senegal, West Africa
}

\begin{abstract}
The inorganic contamination of sediment and harvested molluscs was investigated in the mangrove environment of Southern West Senegal. Trace metals were analysed in surface sediments, two bivalves ( Arca senilis and Crassostera gasar ) and three gastropods ( Conus spp. , Hexaplex duplex and Pugilina morio ) collected from four stations: Dionewar, Niodor and Falia localised in the Saloum Delta, and Fadiouth from the Petite Côte. A geochemical normalisation approach by using aluminium allowed for discrimination of sediment contamination among sites. Indeed, Fadiouth appeared highly contaminated with Cd, $\mathrm{Hg}$ and Ni compared to the Saloum Delta. For all mangrove sites, trace metals exhibited significant higher concentrations (on a dry weight basis) in shellfish compared to sediments, excepted for $\mathrm{Ni}$ and $\mathrm{Pb}$. The distribution pattern followed a similar global trend in molluscs regardless of the spatio-temporal variability, with the predominance of $\mathrm{Zn} \mathrm{(80 \%} \mathrm{of} \mathrm{total}$ metals) followed by $\mathrm{Cu}$ and $\mathrm{Cd}$. However, strong differences of metal bioavailability and bioaccumulation in biota were demonstrated, revealing the requirement of employing a suite of organism bioindicators to monitor metal contamination in mangrove ecosystems. From an ecotoxicological point of view, trace metal levels in sediments from the Petite Côte and the Sine-Saloum Estuary were below the effects range-low (ERL) threshold limit of the sediment quality guidelines for adverse biological effects (SQGs). On the opposite, some concerns about Cd contamination of edible shellfish from Southern West Senegal were highlighted, from both the safety point of view of local populations' health, and the chemical quality point of view of exported resources.
\end{abstract}

N. Bodin (a) , R. N’Gom-Kâ (b,c) , S. Kâ (c) , O.T. Thiaw (c) , L. Tito de Morais (b) , F. Le Loc'h (a,b) , E. Rozuel-Chartier (d) , D. Auger (d) , J.-F. Chiffoleau (d)
(a) CRH, UMR 212 EME, Institut de Recherche pour le Développement, Av Jean Monnet, BP 171, 34203 Sète, France
(b) UMR 195 RAP/LEMAR, Institut de Recherche pour le Développement, Centre de Bel Air, Route des Hydrocarbures, Dakar, Senegal
(c) IUPA, Université Cheikh Anta Diop, BP 5005 Dakar-Fann, Dakar, Senegal
(d) DCN/BE/LBCM, Institut Français de Recherche pour l'Exploitation de la Mer, Rue de l'lle d'Yeu, BP 21105, 44311 Nantes, France 


\section{Introduction}

African mangroves cover over 3.2 million ha corresponding to about $20 \%$ of global coverage, with approximately 1.5 million ha located along the western Atlantic coast. In consequence of the enor- mous pressures and threats they are submitted to within the last past decades, a decline by more than $25 \%$ of the western African mangroves has been observed over the past 25 years (UNEP, 2007). The Senegal, located in West Africa, shelters approximately $6000 \mathrm{~km} 2$ land-area of mangroves distributed along the Southern coast in three main areas: the low Casamance, the Sine-Saloum, and the Petite Côte. These mangroves contribute considerably to the social and economic well-being of the inhabitants of these regions. However, their total surface has been reported to decrease from $1690 \mathrm{~km} 2$ in 1980 to $1287 \mathrm{~km} 2$ in 2006 (UNEP,2007). The government of Senegal and the international community have since taken steps to protect the biodiversity of these sites, and consequently the related socioeconomic activities mainly dominated by fishing and its annex activities (from harvesting of the primary resource to commercialization of further processed fish and seafood products). Hence, the Saloum Delta and Joal-Fadiouth areas from the Sine-Saloum and the Petite Côte are of great con- cern in terms of conservation and management because of the traditional and well-developed fishing activities of Senegal women, particularly the harvesting of diverse mangrove invertebrates. These fisheries play a significant role in artisanal and small-scale commercial activities, and are vital in providing a source of protein

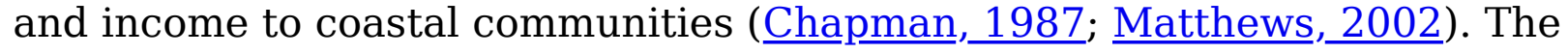
overfishing and modification of water quality due to land-based activities on the marine invertebrates populations might have strong negative consequences on the well-being of local communities (Diouf, 1996; Dia, 2003). In particular, it is of main importance to determine to what extend these mangroves are exposed to anthropogenic pollution, and how it affects commercially important marine species. Since the harvest of marine invertebrates, particularly shellfish, is predominantly a female activity, the decline in these resources may have the dual effect of altering their position within their households and communities, and caus- ing declines in households' levels of food security and operating income (Aswani and Weiant,2004). Among the major pollutants from anthropogenic inputs that reach mangroves are heavy metals (MacFarlane et al.,2007). Metallic enrichment of mangrove environments arises from urban and agricultural runoff, industrial effluents, boating and recrea- tional use of waterbodies, chemical spills, sewage treatment plants, leaching from domestic garbage dumps and mining operations (Peters et al.,1997). Heavy metal toxicity in aquatic organisms, in association with the long residence time within food chains and the potential risk of human exposure, makes it necessary to 
monitor the levels of these contaminants in organisms and more generally in mangrove environment. Sediment is reported to remarkably retain heavy metals (Harbison,1986; Tam and Wong, 1995), and thus is considered as an

appropriate indicator of heavy metal pollution (Idris et al.,2007). However, they are also known to become a secondary source of pollution through remobilization/ resuspension processes back to the water column. Molluscs have also been widely used to monitor the quality of water ecosystems since the late 1980s because of their wide geographical distribution, sessile life-style, ease of sampling, tolerance to a range of salinities, resistance to stress, and

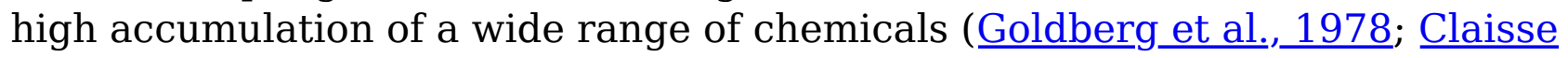
et al.,1992; Rainbow, 1995; Cantillo, 1998). Since the major problem in understanding metal effects on aquatic biota is the high variability in metal bioavailability in the marine environment, the use of several bioindicators improve our abilities to evaluate the bioavailability and bioaccumulation of these chemicals in marine organisms. The main objective of this work was to evaluate the contamination status of trace metals in the mangrove environment of Southern West Senegal. The levels of trace metals were determined in sediment and harvested molluscs belonging to the Sine Saloum and the Petite Côte ecosystems, considering seasonal effect. Poten- tial ecotoxicological concerns were also investigated because of the sanitary importance of knowing the health status of exploited molluscs for human consumption and to contribute with valuable information that allows improving the harvesting activity in these regions.

\section{Material and methods}

\subsection{Description of the sampling areas}

Four areas were investigated in Southern West Senegal: Dionewar, Niodor and Falia in the Saloum Delta, and Fadiouth from the Petite Côte (Fig. 1). The Saloum Delta is located in the northern part of Gambia, $150 \mathrm{~km}$ South of Dakar, between $13^{\circ} 35 \mathrm{~N}$ and $14^{\circ} 15 \mathrm{~N}$, and between $16^{\circ} \mathrm{W}$ and $17^{\circ} \mathrm{W}$. It is a maze of more than 200 islands covered with mangrove swamps, baobabs, kapoks, constituting a network of uncountable bolongs. The Saloum region is one of the most populated in Senegal with 67 inhabitants per $\mathrm{km} 2$, mainly distributed between two cities upstream to the Sine and Saloum rivers: Fatick and Kaolack, with 26,000 and 186,000 inhabitants, respectively (ANSD, 2008a,b). The Saloum region economy is essentially based on farming, fishing, and mangrove exploitation. The whole Delta has been classified as a "Reserve of Biosphere of Unesco" in 1981 and designated as Senegal's third Ramsar Wetland of International Importance in 1984. The delta is also part of the West African Marine Ecoregion (WAMER), one of the WWF's Global 200 ecoregions because of the influence of the Canary Current. The selected areas Dionewar ( \$ 4456 
inhabitants), Falia ( \$ 600 inhabitants) and Niodor ( \$ 6247 inhabitants) are small fishermen villages being part of the rural community of Niodor. Dionewar and Niodor are located close to the mouth of the Saloum Delta, while Falia is located more in the middle of the Saloum Delta (ANSD, 2008a; Sambou et al., 2008). Joal-Fadiouth is a city at the end of the Petite Côte of Senegal, $115 \mathrm{~km}$ Southern East of Dakar, with approximately 35,000 inhabitants (Sambou et al., 2008). The region of the Petite Côte is currently experiencing a process of change of its traditional economy, mainly based on agriculture and fisheries, for the benefit of tourism. The recent and rapid development of an intensive international tourism, which is accompanied by a modernisation of living space on the coastline, is not without raising significant problems in terms of social and economic developments, management and environment degradation with complex interactions.

\subsection{Sample collection and preparation}

The sampling was carried out during two contrasted periods for Fadiouth, Dionewar and Falia: (i) in late October 2007 at the end of the wet season (WS) characterized by mean annual rainfall of $600 \mathrm{~mm}$ and strong South-East winds, (ii) in early June 2008 at the end of the dry season (DS) dominated by hot and dry Harmattan wind ( Wooster et al.,1976; Rebert and Domain, 1977; ANSD, $2007 ; 2008 a)$. For Niordor, samples were collected only at the end of the dry season. The superficial sediment $(0-5 \mathrm{~cm}), 2$ bivalves (A. senilis and Crassostrea gasar ) and 3 gastropods ( Conus spp ., Hexaplex duplex and Pugilina morio ) were collected at low tide by hand on each sta- tion. C. gasar was attached with mangrove prop roots while other fauna was associated with the intertidal mudflat. All samples were immediately packed in plastic bags and stored at low temperature $\left(+4^{\circ} \mathrm{C}\right)$ during transport to the laboratory. Mollusc species were measured, and the soft tissues were excised by stainless steel scalpel blades. Each sample consisted of a pool of 5-20 individuals according to the species. A total number of 16 sediments and 64 pooled samples of molluscan tissues were kept in plastic contain- ers at À $20^{\circ} \mathrm{C}$ until freeze-drying, and then the dry material was ground up using a commercial blender.

\subsection{Trace metal analysis}

Analysis of trace metals was performed on sediments and molluscan tissues following the procedures described by Idardare et al. (2008). Briefly, $200 \mathrm{mg}$ of dried samples were digested by using two different wet acid procedures: mollusc samples were digested with a mixture of hydrochloric and nitric acids in a microwave MARS-5 model microwave oven (CEM Corporation, North Carolina, USA), while sediment samples were digested with a mixture of hydrochloric, nitric and hydrofluoric acids on a heating block (Dig- iPREP MES, 
SCP Sciences). Trace metals ( $\mathrm{Li}, \mathrm{V}, \mathrm{Cr}, \mathrm{Mn}, \mathrm{Co}, \mathrm{Ni}, \mathrm{Cu}, \mathrm{Zn}, \mathrm{Ag}, \mathrm{Cd}, \mathrm{Pb}$, and $\mathrm{Hg}$ ) and the major element Al were analysed by ICP-MS. Fe was analysed by flame atomic absorption spectrometry. The analytical performance were checked using overall six certified reference materials: two sediments, NRCC BCSS-1 and NRCC MESS- 3; three mussel tissues, BCR CRM 278R, IAEA 142 and NIST SRM 2976; and finally one oyster tissue NIST SRM 1566b. All quality control results are shown in Table 1.

\section{Results and discussion}

\subsection{Trace metal contamination in mangrove surface sediments}

The physico-chemical characteristics of the sampling locations and the concentrations of 12 trace elements ( $\mathrm{Li}, \mathrm{V}, \mathrm{Cr}, \mathrm{Mn}, \mathrm{Co}, \mathrm{Ni}, \mathrm{Cu}, \mathrm{Zn}, \mathrm{Ag}, \mathrm{Cd}, \mathrm{Pb}$, and $\mathrm{Hg}$ ) and 2 major elements ( $\mathrm{Al}$ and $\mathrm{Fe}$ ) measured in surface sediment samples are given in Table 2. In Dionewar and Niodor, surface sediment was characterised by fine sands with a water content of $23.1 \pm 1.1 \%$, while sediment from Falia and Fadiouth corresponded to heterogeneous muddy sands with a water content of $23.0 \pm 1.0 \%$ ( Bodin et al.,2011). To compen- sate for the natural variability of the metals in the sediments, as influenced by differences in mineralogy, granulometry and organic matter, a geochemical normalisation approach has been used. It is based on a procedure that involves the mathematical normalisation of heavy metal concentrations to the concentrations of an elemental proxy for mineralogical as well as grain-size changes in sediments (Loring, 1991; Daskalakis and O'Connor, 1995). This approach allows for discrimination of natural versus enriched metals concentrations in coastal sediments, as well as for comparison of metal concentrations among sites and temporal variability within an area. In the present study, significant linear regression trends were obtained between Aluminium and the analysed trace elements measured in mangrove sediments. Aluminium is generally considered to be the most suitable normaliser since it is a major constit- uent of fine grained alumino-silicates (clays) with which the bulk of trace metals are associated, and its concentration in a given area usually exhibits a strong inverse correlation to grain size and positive correlation to co-occurring metal concentrations (Schropp et al.,1990; Daskalakis and O'Connor, 1995; Tam and Yao, 1998; Soto-Jiménez and Páez-Osuna, 2001). It has been suggested that if data points in the regression plot between metal and normaliser concentrations were within the $95 \%$ confidence limits, the sediment metal concentrations were

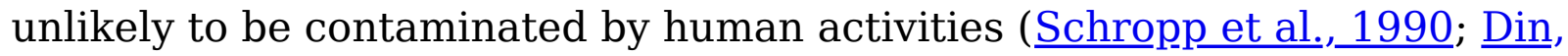
1992; Covelli and Fontolan, 1997). Fig. 2 shows the four main trends revealed by the interpretive tool using metal and aluminium relationships: - Model 1 : $\mathrm{Co}, \mathrm{Li}$ and $\mathrm{Fe}$ were significantly linearly correlated with $\mathrm{Al}$ for all the studied 
areas indicating no form of enrichment for these 3 elements occurs in the mangrove sediments from the Petite Côte and the Sine Saloum Estuary (Fig. 2a). Thus, in addi- tion with $\mathrm{Al}$, at least $\mathrm{Li}$ and $\mathrm{Fe}$ are considered as characteristic of the geological matrix. - Model 2 : Most data for $\mathrm{Mn}$ and $\mathrm{Cr}$ concentrations fell within the 95\% confidence limits, except measurements in Dionewar, indicating that this site was enriched by a factor 2 with these 2 elements (Fig. 2b). - Model 3 : Zn, Cu, V, Ag and Pb concentrations in surface sediments from Falia and Niodor, two sites localised upstream from the Sine Saloum Estuary, seemed linearly correlated with $\mathrm{Al}$, while data from Fadiouth and Dionewar were above the 95\% confidence limits (Fig. 2c). This indicate a slight anthopogenic contamination of these coastal areas with these trace metals that probably occur from an oceanic origin. - Model $4: \mathrm{Cd}, \mathrm{Hg}$ and $\mathrm{Ni}$ concentrations were significantly linearly correlated with $\mathrm{Al}$ for mangrove sediments from the Sine Saloum Estuary (Fig. 2d). On the opposite, all data points at Fadiouth were clearly above the 95\% confidence limits. Cd/Al, $\mathrm{Hg} / \mathrm{Al}$ and $\mathrm{Ni} / \mathrm{Al}$ ratios in Fadiouth sediments were in average 6-, 3- and 2-fold higher, respectively than that in the Sine Saloum sites. These findings suggested that Fadiouth is anthropo- genically contaminated with $\mathrm{Cd}, \mathrm{Hg}$ and Ni. Fadiouth is situated at the end of the Petite Côte, a region of Senegal that is under high economical development especially for tourism. Domestic sewage and industrial effluent discharged from this newly developed city would be the main source of pollution and con- tributed to the high $\mathrm{Cd}, \mathrm{Hg}$ and Ni levels in Fadiouth. The comparison of heavy metal concentrations in this study with that of previous studies in other African countries shows that the concentrations of most heavy metals $(\mathrm{Cr}, \mathrm{Ni}, \mathrm{Cu}, \mathrm{Zn}, \mathrm{Cd}$ and $\mathrm{Pb}$ ) studied in Senegalese mangrove sediments are in the same range than that in Nigeria (Inengite et al.,2010; Benson et al., 2007), and significantly lower than that in other larger African regions such as Morocco, Côte d'Ivoire and Kenya (see online Supplemen- tary material, Table 1). The sediment quality guidelines developed by Bakan and Özkoç_(2007). for marine and estuarine ecosystems were used in the present study to determine the ecotoxicological sense of heavy metal contamination in the sediments of the Petite Côte and the Sine Saloum Estuary. Chemical concentrations corresponding to the 10 th and 50 th percentiles of adverse biological effects were called the effects range-low (ERL) and effects-range median (ERM) guidelines, respectively (Long_et al.,1995). Considering the results, the heavy metal concentrations of the investigated elements were below ERL, representing a minimal-effects range which is intended to estimate conditions where biological effects are rarely observed.

\subsection{Trace metal contamination in mangrove exploited molluscs}

Biological information and concentrations of 7 trace metals $(\mathrm{Ni}, \mathrm{Cu}, \mathrm{Zn}, \mathrm{Ag}, \mathrm{Cd}$, 
$\mathrm{Pb}$, and $\mathrm{Hg}$ ) measured in exploited molluscs from the Petite Côte and the SineSaloum Estuary of Senegal are given in Table 3. For all mangrove sites, trace metals exhibited significant higher concentrations on a dry weight basis in shellfish soft tissues compared to sediment, excepted for $\mathrm{Ni}$ and $\mathrm{Pb}$. No concentration differences between matrices were noticed in the case of $\mathrm{Ni}$, whereas molluscs were 10 times lower contaminated with $\mathrm{Pb}$ than surface sediments. The low bioavalaibility of $\mathrm{Pb}$ for mangrove molluscs has previously been noticed and might be related to its chemical form in the environment (Shulkin et al.,2003). The studied mollusc species exhibited a global trend in their trace metal distribution pattern observed in soft tissues, regardless of the spatial and temporal variability. The main accumulated element was $\mathrm{Zn}$ accounting for $80-85 \%$ of the total metals measured in shellfish, and even until 97\% in Crassostrea gasar . It was followed by $\mathrm{Cu}$ and $\mathrm{Cd}$ representing 15-20\% of the total analysed metals in most species, except in mangrove oysters for which these two elements represented only $2 \%$ of the total metals. Finally, Ni, $\mathrm{Ag}, \mathrm{Pb}$ and $\mathrm{Hg}$ were present at very low concentrations, accounting for less than $3 \%$ to the total metal concentrations in all organisms. However, as depicted in Table 3 and Fig. 3, a more detailed study of the spatial and seasonal distribution of heavy metal accumulation explicitly revealed that the organisms are differentially selec- tive. For many invertebrates including bivalves and gastropods, the diet is the major route of metal uptake. They are considered as potential good bioindicators of the environmental trace metal contamination, providing the chemical analysis of an indirect estimation of the concentration of such substances in their imme- diate environment. However, a variety of biotic and abiotic factors have been identified which can affect the efficiency of trace metal bioaccumulation in mollusc species, such as specimen size, sexual maturity, sensitivity to seasonal, feeding habits, trophic position, water quality and environmental contamination. Even closely related species may be feeding on subtly different food sources with consequently different inputs of metals for accumulation (Rainbow, 1995; Reinfelder et al.,1997; Chong_and Wang, 2000; Luoma and Rainbow, 2005). Indeed, the present study revealed higher $\mathrm{Ni}$ and $\mathrm{Pb}$ bioaccumulation capacities for the bivalve A. senilis, while Crassostrea gasar exhibited the highest $\mathrm{Zn}$ concentrations. The two bivalve species considered are suspension feeders, but they do not live in the same mangrove habitat. On the one hand, the mangrove oyster lives on the prop roots of Rhizophora mangle and receive input of trace metals from the water column (dissolved) and suspended material. On the other hand, the West African cockle is a sediment-dwelling species that accesses oxic water from the water column as well as hypoxic hydrogen sulphide rich water from the organically rich sediment. Such sulphide-rich interstitial water may also be rich in dissolved trace metals in reduced chemical form (Silva et al.,2006). Thus, despite a similar feeding mode, the two bivalves might be exposed to different contamination food sources in relation to their habitat. The in- ter-species variability of heavy metal bioaccumulation pattern may also be due to 
differences of metal assimilation efficiencies between the two bivalves. For example, oysters are notorious for extremely high accumulated $\mathrm{Zn}$ concentrations (Silva et al.,2006), which is confirmed with the mangrove oyster C. gasar from the present study. Finally, the gastropod P. morio , a carnivorous species living on the sediment, seemed to be the more valuable biomonitoring species for $\mathrm{Ag}, \mathrm{Hg}$ and $\mathrm{Cu}$ in the studied ecosystems. The comparison of heavy metal concentrations measured in sediment and molluscs highlighted strong relationships for all studied compounds with one of the studied species, excepted for $\mathrm{Cd}$ (data not shown). Most of the metals ( $\mathrm{Cu}, \mathrm{Zn}, \mathrm{Ag}$, and $\mathrm{Hg}$ ) showed positive correlations between sediment and P. morio levels. As regards $\mathrm{Ni}$, sediment concentrations were positively correlated with those of Arca sensilis . Finally, the two bivalve species ( Arca sensilis and Crassostrea gasar ) seems to be both good bioaccumula- tor for $\mathrm{Pb}$, there soft tissue concentrations being highly correlated to those in sediment. Thus, strictly a single bioindicator of trace metal contamination provides information on the bioavailabilities of metals specifically to that species. A more comprehensive approach would be to employ a suite of organism bioindicators reflecting metal bioavailabilities across a variety of sources such as the water column, suspended particles, sediment, specific food sources, etc. (Rainbow, 1995, Rainbow, 2002; Defew et al.,2005). Although the literature dealing with exploited shellfish contamination in Africa is still insufficient, the comparison of available data with the present results revealed trace metal concentrations in species from Senegal in the same order of magnitude as observed in the other African countries. The considered molluscs in this study are among the most important harvested species in Senegal, and, with fish, they constitute the main protein resources for local population. Moreover, $30-40 \%$ of the fisheries is transformed artisanally, mainly by women, and the transformed products are either consumed in Senegal (around 60\%), or exported essentially in West Africa. Hence, the chemical quality of these marine products (e.g. contaminant contents) is of major importance to resources manag- ers and public health officials of Senegal as they represent a sub- stantial source of foreign currency for developing countries. At present, considerable evidence exists to show that certain heavy metals are a threat to human health when consumed even at trace levels, therefore special attention should be paid to the concentrations of these metals in food from areas impacted by human activity. Currently the regulation of the European Union (EU, 2006) has included 3 metals, $\mathrm{Pb}, \mathrm{Cd}$ and $\mathrm{Hg}$, as dangerous for human consumption. The maximum values of $\mathrm{Pb}$ and $\mathrm{Hg}$ found in exploited molluscs from the Petite Côte and the Sine-Saloum Estuary (Table 3) were below the maximum acceptable limits for seafood, respectively 1.5 and 0.5 micro $\mathrm{g}$ g-1 of wet weight ( $\underline{E}, \underline{2006})$, revealing no potential risk for human, especially local populations. On the opposite, the present study pointed out some concerns about the $\mathrm{Cd}$ contamination of edible shellfish. The maximum acceptable limit of $\mathrm{Cd}$ in edible fishery products is currently 1 micro g g-1 of wet weight (EU, 2006). This threshold limit for Cd was exceeded at all sampling areas, confirming the 
first observa- tions made by Sidoumou et al. (2006). on the North Western Coast of Senegal. Hence, a proper evaluation of the sources of $\mathrm{Cd}$ contamination of the Senegalese coastal marine environment, as well as of the exposure and effects of this trace metal on coastal fisheries is necessary.

\section{Acknowledgements}

This study was part of a project « Femmes et Coquillages » implemented by the Fondation Internationale du Banc d'Arguin (FIBA) and financed by the MAVA Fondation pour la Nature. The authors would like to thank the Senegalese women from Niod- ior, Dionewar, Falia and Fadiouth for their care and their excellent help in sampling mangrove shellfish. We are also grateful to Jean Raffray, Oumar Sadio, Augustin Diokh and Assane Thiam for their technical help at different steps, as well as Pierre Lopez from IRD (UMR 212 EME) for drawing the map.

\section{References}

- Agence Nationale de la Statistique et de la Démographie, 2007. Situation économique et sociale-Région de Fatick, édition 2007. République du Sénégal, p. 127. $<$ http://www.ansd.sn/SRS/fatick_SES.html>.

- Agence Nationale de la Statistique et de la Démographie, 2008a. Situation économique et sociale-Région de Fatick, édition 2008. République du Sénégal, p. 127. $<$ http://www.ansd.sn/SRS/fatick_SES.html>.

- Agence Nationale de la Statistique et de la Démographie, 2008b. Situation économique et sociale-Région de Kaolack, édition 2008. République du Sénégal, p. 158. $<$ http://www.ansd.sn/SRS/kaolack_SES.html>.

- Aswani, S., Weiant, P., 2004. Scientific evaluation in women's participatory management: monitoring marine invertebrate refugia in the Solomon islands. Hum. Organ. 63, 301-319.

- Bakan, G., Özkoç, H.B., 2007. An ecological risk assessment of the impact of heavy metals in surface sediments on biota from the mid-Black Sea coast of Turkey. Int. J. Environ. Stud. $64,45-57$.

- Benson, N.U., Essien, J.P., Bassey, D.E., 2007. Hydrobiological constraints of trace metals in surface water, coastal sediment and water lily of Calabar River, Nigeria. Afr. J. Biotechnol. 6, 2358-2362.

- Bodin, N., N'Gom Kâ, R., Le Loc'h, F., Raffray, J., Budzinski, H., Peluhet, L., Tito de Morais, L., 2011. Are exploited mangrove molluscs exposed to Persistent Organic Pollutant contamination in Senegal, West Africa? Chemosphere 84, 318-327.

- Cantillo, A.Y., 1998. Comparison of results of mussel watch programs of the United States and France with worldwide mussel watch studies. Mar. Pollut. Bull. 36, 712-717.

- Chapman, M.D., 1987. Women's fishing in Oceania. Hum. Ecol. 15, 267-288.

- Chong, K., Wang, W.-X., 2000. Bioavailability of sediment-bound Cd, Cr and Zn to the green mussel Perna viridis and the Manila clam Ruditapes philippinarum . J. Exp. Mar. Biol. Ecol. 255, 75-92.

- Claisse, D., Joanny, M., Quintin, J.Y., 1992. Le Réseau national d'Observation de la qualité 
du milieu marin (RNO). Analysis 20, 19-22.

- Covelli, S., Fontolan, G., 1997. Application of a normalization procedure in determining regional geochemical baselines. Environ. Geol. 30, 34-45.

- Daskalakis, K.D., O'Connor, T.P., 1995. Normalization and elemental sediment contamination in the coastal United States. Environ. Sci. Technol. 29, 470-477.

- Defew, L.H., Mair, J.M., Guzman, H.M., 2005. An assessment of metal contamination in mangrove sediments and leaves from Punta Mala Bay, Pacific Panama. Mar. Pollut. Bull. 50, 547-552.

- Dia, I., 2003. Élaboration et mise en oeuvre d'un plan de gestion intégrée - La Réserve de biosphère du delta du Saloum, Sénégal. Union Internationale pour la Conservation de la Nature (UICN), Dakar, Sénégal, p. 130.

- Din, Z.B., 1992. Use of aluminium to normalize heavy-metal data from estuarine and coastal sediments of Straits of Melaka. Mar. Pollut. Bull. 24, 484-491.

- Diouf, P.S., 1996. Les peuplements de poissons des milieux estuariens de l'Afrique de l'Ouest: l'exemple de l'estuaire hyperhalin du Sine Saloum. PhD thesis, Université de Montpellier II, Montpellier, France, p. 267. <http:// horizon.documentation.ird.fr/exldoc/pleins_textes/pleins_textes_7/TDM_7/010008130.pdf $>$.

- Goldberg, E.D., Bowen, V.T., Farrington, J.W., Harvey, G., Martin, J.H., Parker, P.L., Risebrough, R.W., Robertson, W., Schneider, E., Gamble, E., 1978. The mussel watch. Environ. Conserv. 5, 101-125.

- Harbison, P., 1986. Mangrove muds - a sink and a source for trace metals. Mar. Pollut. Bull. 17, 246-250.

- Idardare, Z., Chiffoleau, J.-F., Moukrim, A., Ait Alla, A., Auger, D., Lefrere, L., Rozuel, E., 2008. Metal concentrations in sediment and Nereis diversicolor in two Moroccan lagoons: Khnifiss and Oualidia. Chem. Ecol. 24, 329-340.

- Idris, A.M., Eltayeb, M.A.H., Potgieter-Vermaak, S.S., Van Grieken, R., Potgieter, J.H., 2007. Assessment of heavy metals pollution in Sudanese harbours along the Red Sea coast. Microchem. J. 87, 104-112.

- Inengite, A.K., Oforka, N.C., Osuji, L.C., 2010. Survey of heavy metals in sediments of Kolo creek in the Niger Delta, Nigeria. Afr. J. Environ. Sci. Technol. 4, 558-566.

- Long, E., Macdonald, D., Smith, S., Calder, F., 1995. Incidence of adverse biological effects within ranges of chemical concentrations in marine and estuarine sediments. Environ. Manage. 19, 81-97.

- Loring, D.H., 1991. Normalization of heavy-metal data from estuarine and coastal sediments. ICES J. Mar. Sci. J. Conseil 48, 101-115.

- Luoma, S.N., Rainbow, P.S., 2005. Why Is metal bioaccumulation so variable? Biodynamics as a unifying concept. Environ. Sci. Technol. 39, 1921-1931.

- MacFarlane, G.R., Koller, C.E., Blomberg, S.P., 2007. Accumulation and partitioning of heavy metals in mangroves: a synthesis of field-based studies. Chemosphere 69, 1454-1464.

- Matthews, E., 2002. Integrating women's subsistence fishing into Pacific fisheries conservation. SPC Women Fish. Inf. Bull. 11, 13-14.

- Official Journal of the European Union (EU), 2006. Commission regulation (EC) No 1881/2006 of 19 December 2006 setting maximum levels for certain contaminants in foodstuffs. L 364/5.

- Peters, E.C., Gassman, N.J., Firman, J.C., Richmond, R.H., Power, E.A., 1997. Ecotoxicology of tropical marine ecosystems. Environ. Toxicol. Chem. 16, 12-40.

- Rainbow, P.S., 1995. Biomonitoring of heavy metal availability in the marine environment. Mar. Pollut. Bull. 31, 183-192.

- Rainbow, P.S., 2002. Trace metal concentrations in aquatic invertebrates: why and so 
what? Environ. Pollut. 120, 497-507.

- Rebert, J.P., Domain, F., 1977. Hydrologie oceanique. In: Atlas national du Senegal. IGN, Paris, pp. 36-39.

- Reinfelder, J.R., Wang, W.X., Luoma, S.N., Fisher, N.S., 1997. Assimilation efficiencies and turnover rates of trace elements in marine bivalves: a comparison of oysters, clams and mussels. Mar. Biol. 129, 443-452.

- Sambou, V., Kébé, C.M.F., Dieye, E.H.B., 2008. Etude sur l'utilisation et la gestion alternative de l'énergie combustible à Fadiouth et dans les îles du Saloum. Fondation Internationale pour le Banc d'Arguin (FIBA) / ENDA GRAF Sahel, Dakar, Sénégal, p. 34. $<$ http://www.lafiba.org/index.php/fr/content/download/2244/14627/version/1/file /033Rapportetudecombustible.pdf>.

- Schropp, S.J., Lewis, F.G., Windom, H.L., Ryan, J.D., Calder, F.D., Burney, L.C., 1990. Interpretation of metal concentrations in estuarine sediment of Florida using aluminium as a reference element. Estuaries 13, 227-235.

- Shulkin, V.M., Presley, B.J., Kavun, 2003. Metal concentrations in mussel Crenomytilus grayanus and oyster Crassostrea gigas in relation to contamination of ambient sediments. Environ. Int. 29, 493-502.

- Sidoumou, Z., Gnassia-Barelli, M., Siau, Y., Morton, V., Roméo, M., 2006. Heavy metal concentrations in molluscs from the Senegal coast. Environ. Int. 32, 384-387.

- Silva, C.A.R.e., Smith, B.D., Rainbow, P.S., 2006. Comparative biomonitors of coastal trace metal contamination in tropical South America (N. Brazil). Mar. Environ. Res. 61, 439-455.

- Soto-Jiménez, M.F., Páez-Osuna, F., 2001. Distribution and normalization of heavy metal concentrations in mangrove and lagoonal sediments from mazatlán harbor (SE Gulf of California). Estuar. Coast. Shelf Sci. 53, 259-274.

- Tam, N.F.Y., Wong, Y.S., 1995. Spatial and temporal variations of heavy metal contamination in sediments of a mangrove swamp in Hong Kong. Mar. Pollut. Bull. 31, 254-261.

- Tam, N.F.Y., Yao, M.W.Y., 1998. Normalisation and heavy metal contamination in mangrove sediments. Sci. Total Environ. 216, 33-39.

- United Nations Environment Programme (UNEP), 2007. Mangroves of Western and Central Africa. UNEP-Regional Seas Programme/UNEP-WCMC. <http:// www.unepwcmc.org/resources/publications/>.

- Wooster, W.S., Bakun, A., Mclain, D.R., 1976. Seasonal upwelling cycle along eastern boundary of North-Atlantic. J. Mar. Res. 34, 131-141. 
Figures and tables

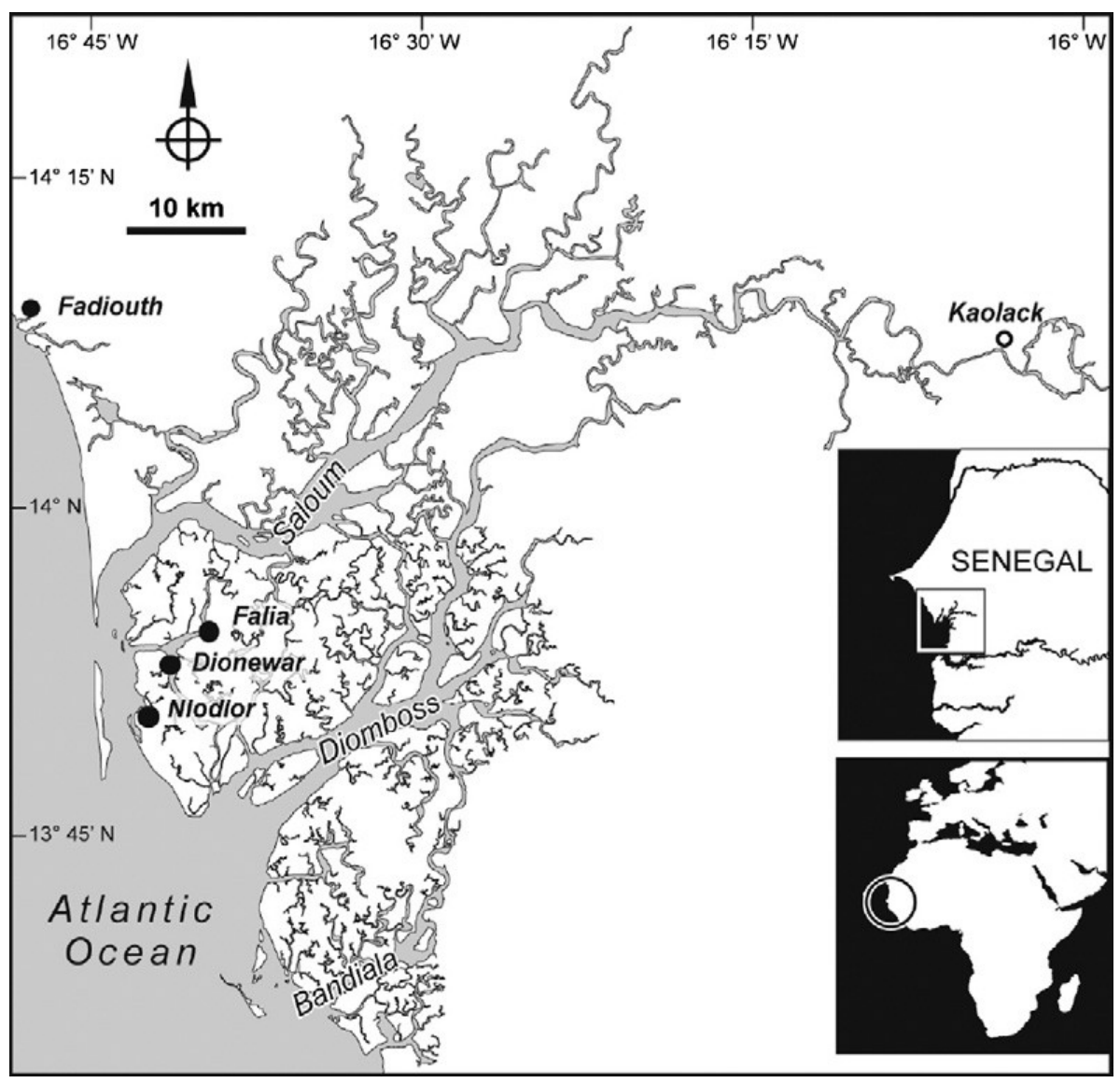

Fig. 1. Map of the sampling stations in Senegal (West Africa): Dionewar, Falia and Niodor from the Sine-Saloum Estuary and Fadiouth from the Petite Côte. 

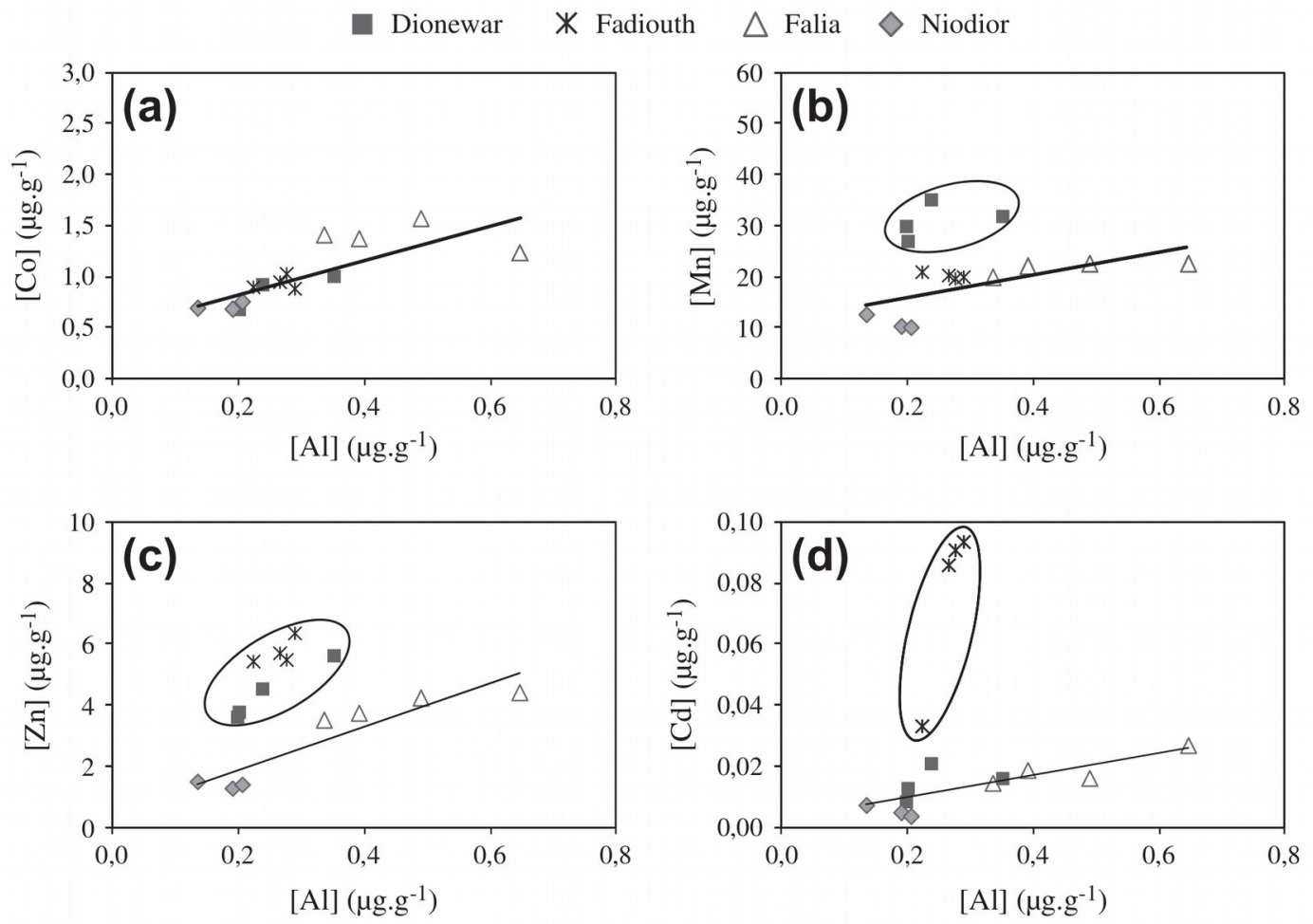

Fig. 2. Relationships between concentrations ( $\mu \mathrm{g} \mathrm{g}^{-1} \mathrm{dw}$ ) of Aluminium and (a) Cobalt, (b) Manganese, (c) Zinc, and (d) Cadmium in mangrove surface sediments from Dionewar, Falia and Niodor localized in the Sine Saloum Estuary, and from Fadiouth localized on the Petite Côte (Senegal).
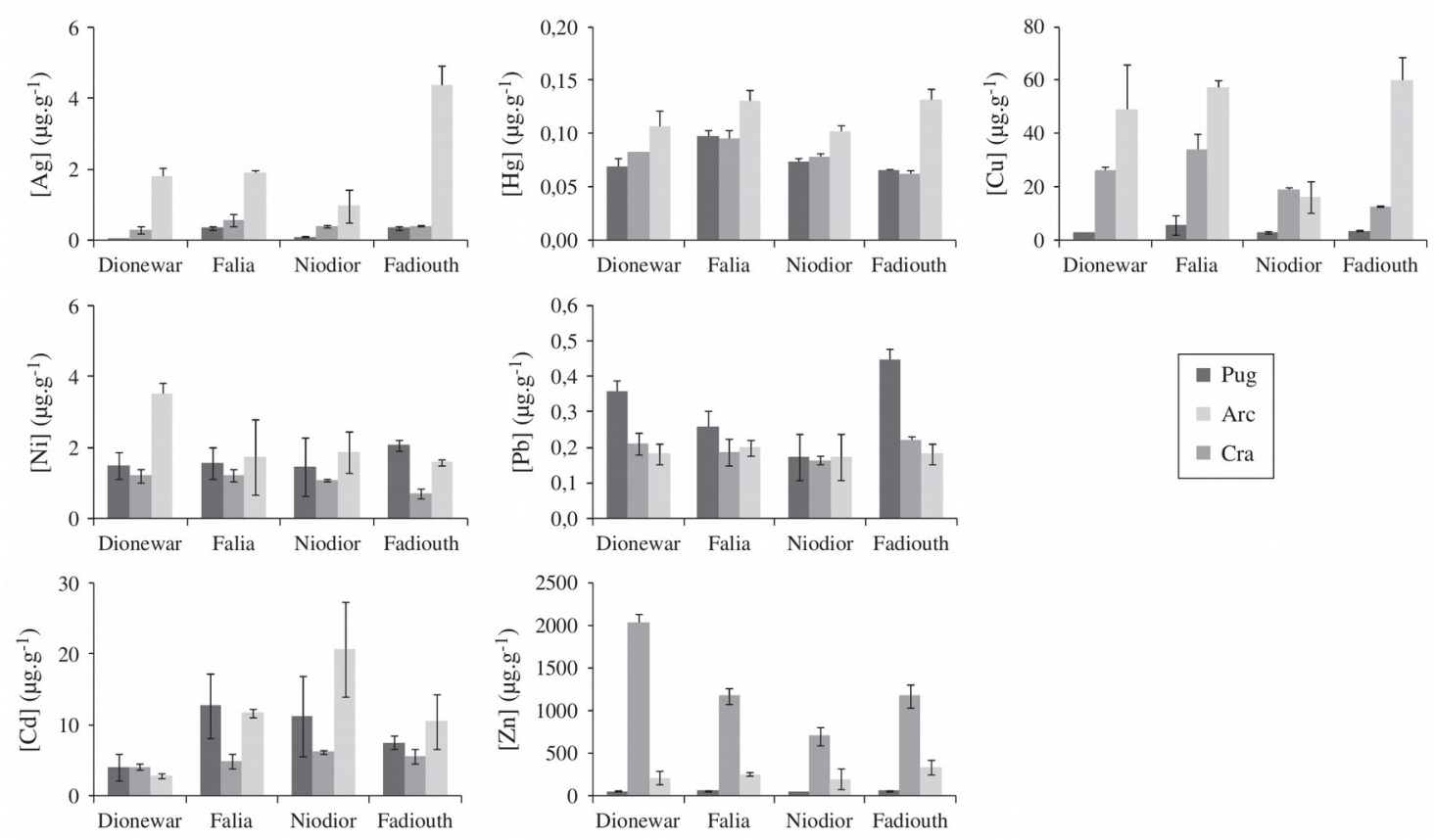

Fig. 3. Concentrations of trace metals $\left(\mu \mathrm{g} \mathrm{g}^{-1} \mathrm{dw}\right)$ measured in exploited molluscs collected at the end of the dry season (DS) from Dionewar, Falia and Niodor localized in the Sine Saloum Estuary, and from Fadiouth localized on the Petite Côte (Senegal). Abbreviates are : $\mathrm{Arc}=$ Arca senilis ; $\mathrm{Cra}=$ Crassostrea gasar $;$ Pug = Pugilina morio. 
Table 1

Quality control performances for trace metal analysis in sediment (a) and biota (b). The six certified reference materials correspond to two sediments (NRCC BCSS-1 and NRCC MESS-3), three mussel tissues (BCR CRM 278R, IAEA 142 and NIST SRM 2976); and one oyster tissue (NIST SRM 1566b). Results are expressed in\% for the major elements (Al and $\mathrm{Fe}$ ), or in $\mu \mathrm{g} \mathrm{g}^{-1} \mathrm{dw}$ for trace metals ( $\mathrm{Ag}, \mathrm{Cd}, \mathrm{Cr}, \mathrm{Cu}, \mathrm{Mn}, \mathrm{Ni}, \mathrm{Pb}$ and $\mathrm{Zn}$ ).

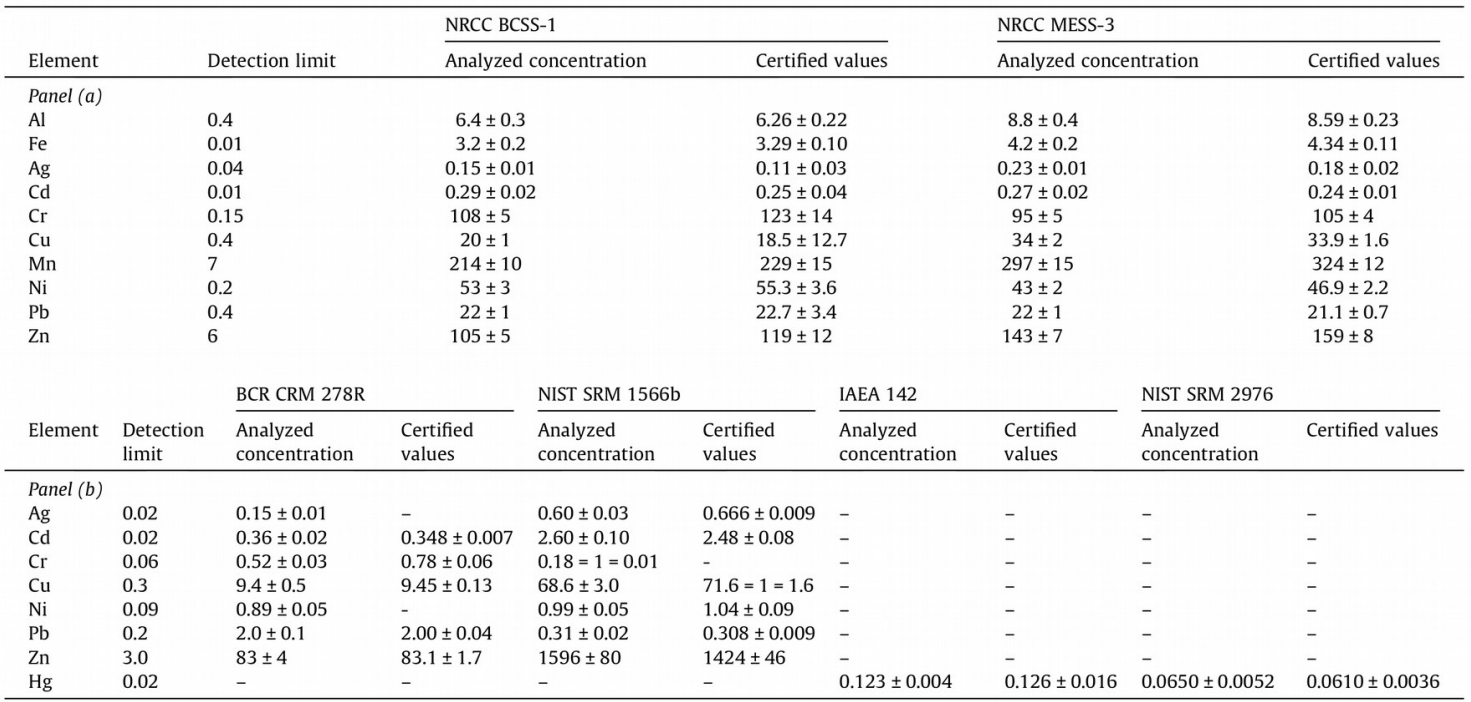

Table 2

Physico-chemical parameters and concentrations of trace metals (mean \pm standard deviation; $\mu \mathrm{g} \mathrm{g}^{-1} \mathrm{dw}$ ) in mangrove surface sediments from the Petite Côte and the Sine Saloum Estuary (Senegal). Abbreviates are: DS = Dry season (May 2008); WS = Wet season (October 2007); $N=$ Number of samples.

\begin{tabular}{|c|c|c|c|c|c|c|c|}
\hline \multirow{2}{*}{$\begin{array}{l}\text { Location } \\
\text { Season }\end{array}$} & \multicolumn{2}{|c|}{ Fadiouth } & \multicolumn{2}{|c|}{ Dionewar } & \multicolumn{2}{|l|}{ Falia } & \multirow{2}{*}{$\begin{array}{l}\text { Niodior } \\
\text { DS }\end{array}$} \\
\hline & WS & DS & WS & DS & WS & DS & \\
\hline \multirow[t]{2}{*}{ Geographic coordinates } & \multicolumn{2}{|c|}{$14^{\circ} 09^{\prime} 18 \mathrm{~N}$} & \multicolumn{2}{|c|}{$13^{\circ} 53^{\prime} 34 \mathrm{~N}$} & \multicolumn{2}{|c|}{$13^{\circ} 54^{\prime} 29 \mathrm{~N}$} & $13^{\circ} 50^{\prime} 57 \mathrm{~N}$ \\
\hline & \multicolumn{2}{|c|}{$\begin{array}{l}16^{\circ} 49^{\prime} 37 \mathrm{~W} \\
1.8\end{array}$} & \multicolumn{2}{|c|}{$16^{\circ} 43^{\prime} 55 \mathrm{~W}$} & \multicolumn{2}{|c|}{$16^{\circ} 42^{\prime} 08 \mathrm{~W}$} & $16^{\circ} 44^{\prime} 08 \mathrm{~W}$ \\
\hline$T\left({ }^{\circ} \mathrm{C}\right)$ & 28.4 & 26.4 & 28.2 & 25.5 & 28.6 & 28.7 & 27.4 \\
\hline Salinity & 35 & 40 & 34 & 41 & 34 & 40 & 40 \\
\hline$N$ & 1 & 3 & 1 & 3 & 1 & 3 & 3 \\
\hline $\mathrm{Al}$ & 0.22 & $0.28 \pm 0.01$ & 0.35 & $0.21 \pm 0.02$ & 0.65 & $0.41 \pm 0.08$ & $0.18 \pm 0.04$ \\
\hline $\mathrm{Cd}$ & 0.033 & $0.090 \pm 0.004$ & 0.016 & $0.014 \pm 0.006$ & 0.027 & $0.016 \pm 0.002$ & $0.005 \pm 0.002$ \\
\hline Co & 0.9 & $0.9 \pm 0.1$ & 1.0 & $0.8 \pm 0.1$ & 1.2 & $1.4 \pm 0.1$ & $0.7 \pm 0.0$ \\
\hline $\mathrm{Cr}$ & 28.8 & $23.6 \pm 2.7$ & 31.5 & $27.9 \pm 4.7$ & 26.0 & $20.9 \pm 1.0$ & $16.7 \pm 1.1$ \\
\hline $\mathrm{Cu}$ & 3.5 & $3.6 \pm 0.3$ & 3.3 & $2.7 \pm 0.5$ & 3.1 & $2.5 \pm 0.1$ & $1.2 \pm 0.2$ \\
\hline $\mathrm{Hg}$ & 0.013 & $0.008 \pm 0.003$ & 0.005 & $0.005 \pm 0.001$ & 0.01 & $0.006 \pm 0.001$ & $0.004 \pm 0.001$ \\
\hline $\mathrm{Li}$ & 4.0 & $4.3 \pm 0.1$ & 4.9 & $3.7 \pm 0.5$ & 8.4 & $6.4 \pm 0.8$ & $3.5 \pm 0.0$ \\
\hline Mn & 21.0 & $19.8 \pm 0.4$ & 31.7 & $30.5 \pm 4.1$ & 22.4 & $21.4 \pm 1.3$ & $10.8 \pm 1.4$ \\
\hline
\end{tabular}


Table 3

Concentrations of trace metals (mean \pm standard deviation; $\mu \mathrm{g} \mathrm{g}^{-1} \mathrm{dw}$ ) in harvested molluscs from the Petite Côte and the Sine Saloum Estuary (Senegal). Abbreviates are: Arc = Arca senilis; Cra =Crassostrea gasar; Con=Conus spp.; Hex = Hexaplex duplex; Pug = Pugilina morio; DS = Dry season (May 2008); WS= Wet season (October 2007); $N=$ Number of samples; $n=$ Number of individuals pooled per sample; $\mathrm{TL}=$ Total length $(\mathrm{mm})$.

\begin{tabular}{|c|c|c|c|c|c|c|c|c|c|c|c|}
\hline Location & Season & Sample & $N(n)$ & $\mathrm{TL}$ & $\mathrm{Ni}$ & $\mathrm{Cu}$ & Zn & $\mathrm{Ag}$ & $\mathrm{Cd}$ & $\mathrm{Pb}$ & $\mathrm{Hg}$ \\
\hline \multirow[t]{9}{*}{ Fadiouth } & \multirow[t]{5}{*}{ DS } & Arc & $3(20)$ & $31 \pm 0.4$ & $2.1 \pm 0.1$ & $3.5 \pm 0.1$ & $57 \pm 3$ & $0.35 \pm 0.05$ & $7.5 \pm 0.9$ & $0.45 \pm 0.03$ & $0.066 \pm 0.002$ \\
\hline & & Con & $3(6)$ & $70 \pm 0.1$ & $1.7 \pm 0.5$ & $18.5 \pm 2.1$ & $155 \pm 17$ & $1.20 \pm 0.06$ & $9.2 \pm 1.2$ & $0.14 \pm 0.02$ & $0.069 \pm 0.009$ \\
\hline & & Cra & $3(20)$ & $48 \pm 1.0$ & $0.7 \pm 0.1$ & $12.7 \pm 0.1$ & $1170 \pm 139$ & $0.41 \pm 0.02$ & $5.5 \pm 1.1$ & $0.22 \pm 0.01$ & $0.063 \pm 0.003$ \\
\hline & & Hex & $3(6)$ & $76 \pm 1.4$ & $2.1 \pm 0.9$ & $62.5 \pm 12.1$ & $273 \pm 22$ & $2.57 \pm 0.35$ & $10.8 \pm 1.9$ & $0.17 \pm 0.03$ & $0.191 \pm 0.023$ \\
\hline & & Pug & $3(6)$ & $85 \pm 1.0$ & $1.6 \pm 0.1$ & $59.9 \pm 9.0$ & $332 \pm 85$ & $4.36 \pm 0.56$ & $10.4 \pm 3.9$ & $0.18 \pm 0.03$ & $0.132 \pm 0.010$ \\
\hline & \multirow[t]{4}{*}{ WS } & Arc & $4(35)$ & $36 \pm 0.5$ & $0.7 \pm 0.1$ & $2.6 \pm 0.3$ & $62 \pm 2$ & $0.37 \pm 0.27$ & $5.9 \pm 1.7$ & $0.28 \pm 0.04$ & $0.081 \pm 0.010$ \\
\hline & & Cra & $1(22)$ & 56 & 1.7 & 28.8 & 2117 & 1.53 & 7.6 & 0.44 & 0.105 \\
\hline & & Hex & $1(11)$ & 69 & 3.9 & 22.4 & 220 & 0.60 & 10.9 & 0.24 & 0.140 \\
\hline & & Pug & $1(20)$ & 70 & 5.5 & 26.0 & 84 & 1.09 & 3.7 & 0.24 & 0.084 \\
\hline \multirow[t]{6}{*}{ Dionewar } & \multirow[t]{3}{*}{ DS } & Arc & $3(20)$ & $28 \pm 0.6$ & $1.5 \pm 0.4$ & $2.9 \pm 0.1$ & $57 \pm 2$ & $0.02 \pm 0.01$ & $4.0 \pm 1.9$ & $0.36 \pm 0.03$ & $0.069 \pm 0.008$ \\
\hline & & Cra & $3(20)$ & $55 \pm 0.9$ & $1.2 \pm 0.2$ & $26.0 \pm 1.5$ & $2032 \pm 105$ & $0.29 \pm 0.11$ & $4.1 \pm 0.4$ & $0.21 \pm 0.03$ & $0.083 \pm 0.001$ \\
\hline & & Pug & $3(4)$ & $91 \pm 2.4$ & $3.5 \pm 0.3$ & $49.1 \pm 16.7$ & $213 \pm 82$ & $1.79 \pm 0.24$ & $2.8 \pm 0.3$ & $0.18 \pm 0.03$ & $0.107 \pm 0.014$ \\
\hline & \multirow[t]{3}{*}{ WS } & $\operatorname{Arc}$ & $1(14)$ & 43 & 0.9 & 3.3 & 59 & 0.07 & 8.8 & 0.47 & 0.079 \\
\hline & & Cra & $1(20)$ & 50 & 1.4 & 27.1 & 1744 & 0.30 & 4.1 & 0.24 & 0.086 \\
\hline & & Pug & $1(19)$ & 73 & 2.8 & 77.5 & 641 & 1.48 & 8.3 & 0.32 & 0.108 \\
\hline \multirow[t]{10}{*}{ Falia } & \multirow[t]{5}{*}{ DS } & $\operatorname{Arc}$ & $3(20)$ & $29 \pm 0.8$ & $1.5 \pm 0.4$ & $5.7 \pm 3.6$ & $61 \pm 6$ & $0.34 \pm 0.05$ & $12.7 \pm 4.6$ & $0.26 \pm 0.05$ & $0.098 \pm 0.005$ \\
\hline & & Con & $3(6)$ & $55 \pm 2.5$ & $3.5 \pm 1.1$ & $9.8 \pm 0.5$ & $139 \pm 23$ & $0.60 \pm 0.03$ & $7.8 \pm 1.3$ & $0.25 \pm 0.03$ & $0.101 \pm 0.009$ \\
\hline & & Сra & $3(20)$ & $53 \pm 3.6$ & $1.2 \pm 0.2$ & $34.2 \pm 5.6$ & $1174 \pm 93$ & $0.57 \pm 0.17$ & $4.9 \pm 1.0$ & $0.19 \pm 0.04$ & $0.095 \pm 0.008$ \\
\hline & & Hex & $1(6)$ & 72 & 2.2 & 17.0 & 291 & 0.21 & 12.1 & 0.18 & 0.121 \\
\hline & & Pug & $3(6)$ & $83 \pm 3.7$ & $1.7 \pm 1.1$ & $57.2 \pm 2.9$ & $251 \pm 22$ & $1.88 \pm 0.07$ & $11.7 \pm 0.6$ & $0.20 \pm 0.02$ & $0.130 \pm 0.010$ \\
\hline & \multirow[t]{5}{*}{ WS } & $\operatorname{Arc}$ & $1(20)$ & 35 & 1.5 & 4.1 & 66 & 0.26 & 26.1 & 0.42 & 0.103 \\
\hline & & Con & $1(21)$ & 66 & 2.8 & 12.7 & 115 & 0.75 & 10.0 & 0.21 & 0.095 \\
\hline & & Cra & $1(9)$ & 47 & 1.7 & 33.1 & 1161 & 0.50 & 5.9 & 0.15 & 0.098 \\
\hline & & Hex & $1(18)$ & 117 & 2.8 & 25.0 & 211 & 0.92 & 26.9 & 0.17 & 0.100 \\
\hline & & Pug & $1(37)$ & 87 & 5.1 & 56.0 & 163 & 1.09 & 17.5 & 0.17 & 0.116 \\
\hline \multirow[t]{4}{*}{ Niodior } & \multirow[t]{4}{*}{ DS } & $\operatorname{Arc}$ & $3(20)$ & $29 \pm 0.2$ & $1.5 \pm 0.8$ & $3.0 \pm 0.4$ & $51 \pm 3$ & $0.10 \pm 0.03$ & $11.2 \pm 5.7$ & $0.17 \pm 0.07$ & $0.074 \pm 0.003$ \\
\hline & & Cra & $3(20)$ & $56 \pm 1.2$ & $1.1 \pm 0.03$ & $13.5 \pm 0.9$ & $699 \pm 108$ & $0.39 \pm 0.04$ & $6.2 \pm 0.3$ & $0.16 \pm 0.01$ & $0.078 \pm 0.004$ \\
\hline & & Hex & $3(6)$ & $73 \pm 2.6$ & $1.6 \pm 0.6$ & $18.9 \pm 1.1$ & $453 \pm 10$ & $0.62 \pm 0.06$ & $17.7 \pm 2.5$ & $0.17 \pm 0.05$ & $0.101 \pm 0.007$ \\
\hline & & Pug & $3(6)$ & $80 \pm 3.7$ & $1.9 \pm 0.6$ & $16.2 \pm 6.1$ & $197 \pm 122$ & $0.96 \pm 0.45$ & $20.6 \pm 6.7$ & $0.17 \pm 0.06$ & $0.102 \pm 0.006$ \\
\hline
\end{tabular}

